\title{
MELATONIN AND SOME PARAMETERS OF CELL-ME- DIATED IMMUNE RESPONSE IN PATIENTS WITH CHRONIC RHINOSINUSITIS WITHOUT NASAL POLYPS
}

\author{
Kharkiv National Medical University, Kharkiv, Ukraine
}

\begin{abstract}
Chronic rhinosinusitis is a polyetiological disease, the pathogenesis of which is currently being actively studied. It has been known that Th1 type of immune response prevails in chronic rhinosinusitis without nasal polyps. In addition to cytokines that contributes to the activation of cell-mediated immunity, melatonin may be involved in the regulation of the subtype of immune response. Concentrations of IL-8, IL-12 and melatonin in blood serum of patients with exacerbation of chronic rhinosinusitis without nasal polyps (n $=20)$ and healthy individuals with deviated nasal septum $(n=20)$, who served as the control group, were determined using the corresponding ELISA kits. Analysis of obtained data was carried out using the Graph Pad Prism 5 application with the help of the MannWhitney $\mathrm{U}$ test. It was shown that exacerbation of chronic rhinosinusitis without nasal polyps was accompanied by melatonin deficiency against the background of elevated concentrations of Th1-associated proinflammatory cytokines IL-8 and IL-12 in blood serum. Melatonin has been known to affect the expression of IL-8 and IL-12. Thus, melatonin, acting via proinflammatory cytokines, can affect the differentiation of naïve immature CD4+ cells in Th1-cells, promoting realization of the immune response in the cell-mediated direction. Our conclusions about the prevalence of cell-mediated Th1-related immune response in chronic rhinosinusitis without nasal polyps are consistent with the data of other authors. Thus, exacerbation of chronic rhinosinusitis without nasal polyps is accompanied by a twofold increase in serum IL-12 and a threefold increase in serum IL-8 levels against the background of noticeable lack of melatonin, which may indicate the role of melatonin deficiency in the activation of the cell-mediated immunity.
\end{abstract}

KeyWords: chronic rhinosinusitis, rhinosinusitis without nasal polyps, interleukins, melatonin, inflammation, interleukin-8, interleukin12.



\section{INTRODUCTION}

Chronic rhinosinusitis has been known to be a multifactorial and heterogeneous disease the etiology and pathogenesis of which are being currently studied. Nowadays two histopathologic types of chronic rhinosinusitis are distinguished: rhinosinusitis with and without nasal polyps [1-3]. Both types of chronic rhinosinusitis are characterized by changes in blood serum cytokine profile [4 - 7].

Chronic rhinosinusitis without nasal polyps is characterized by inflammation accompanied by overproduction of type 1 helper T cell (Th1)-associated proinflammatory cytokines, which indicates the prevalence of cell-mediated Th1-subtype of immune response [8].

\section{Corresponding Author:}

Anton Tkachenko, MD, PhD, Assistant Professor, Biochemistry Department, Kharkiv National Medical University, Ukraine.
However, in addition to cytokines, other factors may contribute to the regulation of immune response subtype. One of such factors is melatonin, which is produced by the pineal gland. It has been reported that this hormone can affect the rate and subtype of inflammation due to its antioxidant properties and via regulation of cytokine synthesis $[9,10]$. In particular, melatonin is involved in regulation of IL-12 and IL-8 formation, which are known to promote differentiation of naïve CD4+ cells into Th1-cells [11 - 13].

Thus, the interplay between melatonin and cytokines in the complex response of immune system determines features of the inflammatory process. The role of melatonin in shifting differentiation of naïve T-cells towards Th1- or Th2cells and effects of this pineal hormone on the mechanism underlying cytokine crosstalk and regulation of the immune response type have not been fully elucidated yet. 


\section{PURPOSES, SUBJECTS and METHODS:}

2.1 Purpose of our research was to study the content of proinflammatory cytokines IL-8 and IL-12 that activate cell-mediated immune response in blood serum and serum melatonin levels, as well as their interplay, in patients with chronic rhinosinusitis without nasal polyps.

\subsection{Subjects \& Methods}

We examined 40 patients of Kharkiv Regional Clinical Hospital. All individuals were randomly subdivided into two equal groups. Group 1 included patients who had been diagnosed with exacerbation of chronic rhinosinusitis without nasal polyps $(n=20)$. Clinical examination, laboratory and instrumental tests in accordance with criteria offered by the WHO expert committee were used to verify their diagnosis. Group 2 served as control and consisted of twenty healthy individuals with deviated nasal septum $(n=20)$. Patients from group 2 did not show any signs of acute or chronic pathology, endocrine diseases, obesity, oncologic diseases, and hypertension. Pregnant females were excluded. Informed consent was obtained from every patient.

All activities were performed according to The Code of Ethics of the World Medical Association (Declaration of Helsinki) and Convention for the Protection of Human Rights and Dignity of the Human Being with regard to the Application of Biology and Medicine (ETC 164).

Levels of IL-8, IL-12 and melatonin were measured in blood serum samples using enzyme-linked immunosorbent assay kits manufactured by Vector-Best (Russian Federation), Orgenium (Finland), IBL Hamburg (Germany), respectively, in accordance with instructions provided by manufacturers. The Awareness Technology Stat Fax 303 Plus Microstrip Reader was used to register the optical density of solutions.

Statistical analysis of the data obtained in our research was performed using GraphPad Prism 5. Mann-Whitney test was used to detect differences between groups. Values are presented as median and interquartile range $(25$ th - 75th percentage). Difference between groups was considered to be statistically significant at $p<0.05$.

\section{Conflict of interests}

There is no conflict of interests.

\section{$3 \quad$ RESULTS AND DISCUSSION}

It was found that blood levels of melatonin were over 3 times lower in patients with exacerbation of chronic rhinosinusitis without nasal polyps compared to the control group (Fig. 1). Melationin concentration in group 1 reached 33.24 $(29.15 ; 39.78) \mathrm{pg} / \mathrm{ml}$, while in group 2 its serum levels were $10.30(9.45 ; 13.03) \mathrm{pg} / \mathrm{ml}$.



Fig. 1. The content of melatonin in blood serum of patients with chronic rhinosinusitis without nasal polyps

Reduction of melatonin may contribute to the activation of inflammatory process, taking into account its antioxidant properties. Similar changes in blood serum melatonin concentrations were observed in chronic rhinosinusitis with nasal polyps [14]. However, melatonin deficiency was less pronounced in patients with the form of rhinosinusitis mentioned above. It has been reported that melatonin inhibits translocation of NF-KB to the nucleus and its attachment to DNA, which results in downregulation of the expression of certain proinflammatory cytokines [15 - 17]. Thus, we be- 
lieve that the lack of melatonin in patients with chronic rhinosinusitis without nasal polyps may make the course of the disease more severe due to upregulation of TNF- $a$ and other proinflammatory cytokines. Nevertheless, while considering the role of the hormone produced by the pineal gland in the pathogenesis of exacerbation of chronic rhinosinusitis without nasal polyps, it is necessary to take into account the interplay of melatonin and cytokines. Melatonin has been known to interact with the immune system at the level of the synthesis of cytokines by immune cells. For example, García-Mauriño S. et al demonstrated that melatonin was able to upregulate IL-12 expression by macrophages [11].

IL-12 blood serum levels in patients from group 1 were found to be $19.45(14.65 ; 25.21) \mathrm{ng} / \mathrm{ml}$ against 9.43 (9.16; $10.43) \mathrm{ng} / \mathrm{ml}$ in group 2.

Despite the fact that the level of IL-12 is twice high in patients with rhinosinusitis without nasal polyps compared to healthy individuals (Fig. 2), its level is lower in comparison with patients with chronic rhinosinusitis with nasal polyps.

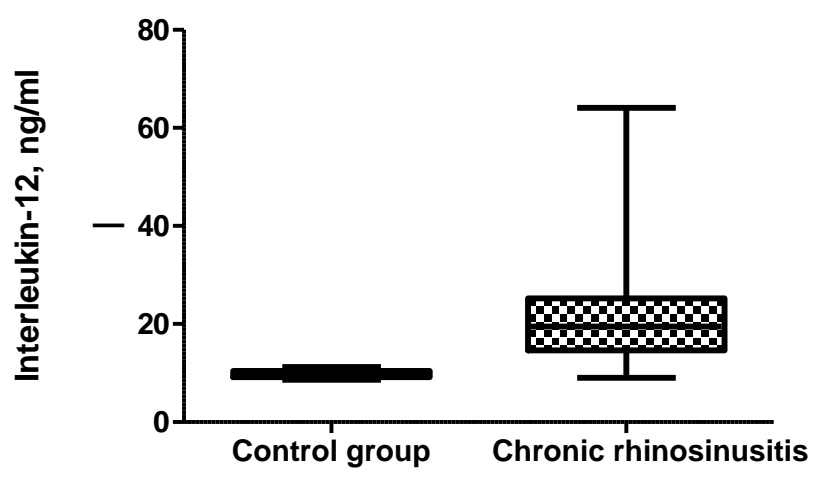

Fig. 2. Levels of IL-12 in blood serum of patients with chronic rhinosinusitis without nasal polyps

Thus, we believe that the more pronounced melatonin deficiency in exacerbation of chronic rhinosinusitis without nasal polyps results in preventing overactivation of IL-12 and maintaining the balance between factors that activate cellmediated and humoral immune responses. This fact emphasizes the role of interplay between IL-12 and melatonin in regulation of the immune response in chronic rhinosinusitis without nasal polyps.

However, it is worth mentioning that melatonin downregulates IL-8 $[12,13,18]$. Thus, the action of melatonin may contribute to an increase in IL-8 concentrations in patients with chronic rhinosinusitis without nasal polyps. Its levels reach $22.75(3.8 ; 47.0) \mathrm{pg} / \mathrm{ml}$ and are significantly ( $\mathrm{p} 00.05)$ 3.1 times higher than in healthy people from the control group (Fig. 3) whose IL-8 serum concentrations reach 7.25 (3.86; 16.93$) \mathrm{pg} / \mathrm{ml}$, while in patients with chronic rhinosinusitis with nasal polyps serum IL-8 levels decrease [19].

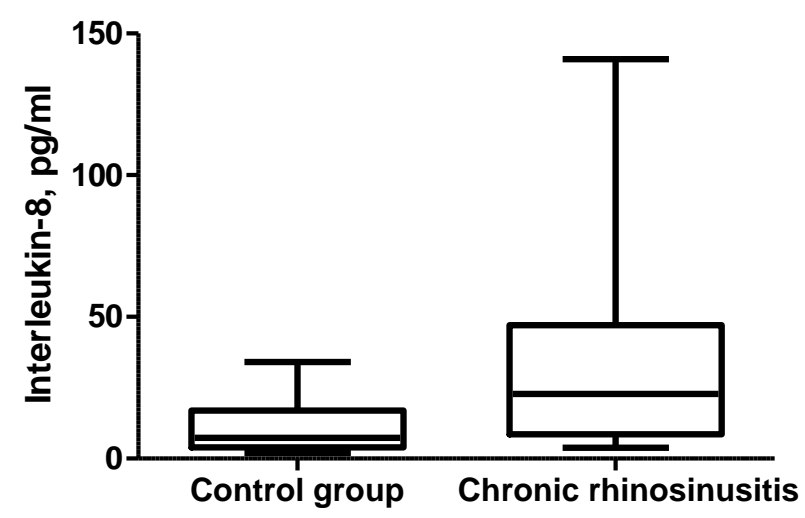

Fig. 3. Concentrations of IL-8 in blood serum of patients with chronic rhinosinusitis without nasal polyps

In general, the slight elevation of IL-12 and the noticeable increase in IL-8 levels may be considered as a sign of the activation of cell-mediated immunity. The data obtained in our research on the predominance of the cell-mediated link of immunity in chronic rhinosinusitis without nasal polyps are consistent with the results of other authors [20, 21].

\section{CONCLUSIONS}

1. Exacerbation of chronic rhinosinusitis without nasal polyps is characterized by elevation of IL- 8 and IL-12 blood serum levels against the background of melatonin deficiency.

2. Melatonin may be involved in regulating the immune response type in chronic rhinosinusitis without nasal polyps via IL-8 and II-12.

3. Melatonin deficiency promotes the prevalence of cellmediated immune response in chronic rhinosinusitis without 
nasal polyps.

\section{REFERENCES}

1. Schleimer, R.P. (2017). Immunopathogenesis of Chronic Rhinosinusitis and Nasal Polyposis. Annual Review of Pathology, 12, 331-357. http://doi.org/10.1146/annurevpathol-052016-100401.

2. Mahdavinia, M., Keshavarzian, A., Tobin, M.C., Landay, A., Schleimer, R.P. (2016). A comprehensive review of the nasal microbiome in chronic rhinosinusitis (CRS). Clinical and Experimental Allergy: Journal of the British Society for Allergy and Clinical Immunology, 46(1), 21-41. http://doi.org/10.1111/cea.12666.

3. DeYoung, K., Wentzel, J.L., Schlosser, R.J., Nguyen, S.A., Soler, Z.M. (2014). Systematic review of immunotherapy for chronic rhinosinusitis. Am J Rhinol Allergy, 28(2), 145-150. doi: 10.2500/ajra.2014.28.4019.

4. Onischenko, A.I., Nakonechna, O.A., Tkachenko, A.S., Kalashnik, Yu.M. (2017). The content of MCP-1 and MMP-9 in blood serum of patients with chronic polypoid rhinosinusitis. The Journal of V.N. Karazin Kharkiv National University. Series “Medicine”, 33, 23-26.

5. Tsybikov, N.N., Egorova, E.V., Kuznik, B.I., Fefelova, E.V., Magen, E. (2015). Anticytokine autoantibodies in chronic rhinosinusitis. Allergy Asthma Proc., 36(6), 473-80. doi: 10.2500/aap.2015.36.3880.

6. Shah, S.A., Ishinaga, H., Takeuchi, K. (2016). Pathogenesis of eosinophilic chronic rhinosinusitis. Journal of Inflammation (London, England), 13,11. doi:10.1186/s12950-016-0121-8.

7. Divekar, R.D., Samant, S., Rank, M.A., Hagan, J., Lal, D., O'Brien, E.K., Kita, H. (2015). Immunological profiling in chronic rhinosinusitis with nasal polyps reveals distinct VEGF and GMCSF signatures during symptomatic exacerbations. Clinical and Experimental Allergy : Journal of the British Society for Allergy and Clinical Immunology, 45(4), 767-778. http://doi.org/10.1111/cea.12463

8. Lee, S., Lane, A.P. (2011). Chronic Rhinosinusitis as a Multifactorial Inflammatory Disorder. Current infectious disease reports, 13(2), 159-168. doi:10.1007/s11908-0110166-z.
9. Cutolo, M., Maestroni, G. (2005). The melatonincytokine connection in rheumatoid arthritis. Annals of the Rheumatic Diseases, 64(8), 1109-1111. http://doi.org/10.1136/ard.2005.038588.

10. Yu, G-M., Kubota, H., Okita, M., Maeda, T. (2017). The anti-inflammatory and antioxidant effects of melatonin on LPS-stimulated bovine mammary epithelial cells. PLoS ONE, 12(5), e0178525. http://doi.org/10.1371/journal.pone. 0178525.

11. García-Mauriño, S., Pozo, D., Carrillo-Vico, A., Calvo, J.R., Guerrero, J.M. (1999). Melatonin activates Th1 lymphocytes by increasing IL-12 production. Life Sci., 65(20), 2143-50.

12. Kim, G.D., Lee, S.E., Kim, T.H., Jin, Y.H., Park, Y.S., Park, C.S. (2012). Melatonin suppresses acrolein-induced IL8 production in human pulmonary fibroblasts. J Pineal Res., 52(3), 356-64. doi: 10.1111/j.1600-079X.2011.00950.x.

13. Silva, S.O., Rodrigues, M.R., Ximenes, V.F., Buenoda-Silva, A.E., Amarante-Mendes, G.P., Campa, A. (2004). Neutrophils as a specific target for melatonin and kynuramines: effects on cytokine release. J Neuroimmunol., 156(1-2), 146-52.

14. Onischenko, A.I., Nakonechna, O.A., Tkachenko, A.S. (2017). Changes in the content of melatonin and IL-12 in blood serum of patients with chronic polypoid rhinosinusitis, Buk. Med. Herald. 21, 2(82), 75-77. DOI:10.24061/2413-0737/XXI.2.82.2.2017.63

15. Reiter, R.J., Calvo, J.R., Karbownik, M., Qi, W., Tan, D.X. (2000). Melatonin and its relation to the immune system and inflammation. Ann. N. Y. Acad. Sci., 917, 37686.

16. García, J.A., Volt, H., Venegas, C., Doerrier, C., Escames, G., López, L.C., Acuña-Castroviejo, D. (2015). Disruption of the NF-kB/NLRP3 connection by melatonin requires retinoid-related orphan receptor- $\alpha$ and blocks the septic response in mice. FASEB J., 29(9), 3863-3875. doi: 10.1096/fj.15-273656.

17. Shrestha, S., Zhu, J., Wang, Q., Du, X., Liu, F., Jiang, J., ... Song, X. (2017). Melatonin potentiates the antitumor effect of curcumin by inhibiting IKKB/NF-KB/COX2 signaling pathway. International Journal of Oncology, 
51(4), 1249-1260. http://doi.org/10.3892/ijo.2017.4097

18. Carrillo-Vico, A., Lardone, P.J., Álvarez-Sánchez, N., Rodríguez-Rodríguez, A., Guerrero, J.M. (2013). Melatonin: Buffering the Immune System. International Journal of Molecular Sciences, 14(4), 8638-8683. http: //doi.org/10.3390/ijms14048638

19. Nakonechnaya, O.A., Onishchenko, A.I. (2016). The content of interleukin- 8 and matrix metalloproteinase- 9 in blood of patients with exacerbation of chronic purulent and polypoid rhinosinusitis. Aktualnyie problemyi meditsinyi: Respublikanskaya nauchno-prakticheskaya konferentsiya s mezhdunarodnyim uchastiem, Gomel, 101-106.
20. Ikeda, K., Shiozawa, A., Ono, N., Kusunoki, T., Hirotsu, M., Homma, H., Saitoh, T., Murata, J. (2013). Subclassification of chronic rhinosinusitis with nasal polyp based on eosinophil and neutrophil. Laryngoscope, 123,1-9. 21. Cho, S.W., Kim, D.W., Kim, J.W., Lee, C.H., Rhee, C.S. (2017). Classification of chronic rhinosinusitis according to a nasal polyp and tissue eosinophilia: limitation of current classification system for Asian population. Asia Pac Allergy, 7(3), 121-130.

Received: $\quad$ 01-Sep. - 2017

Accepted: $\quad$ 13-Dec. - 2017

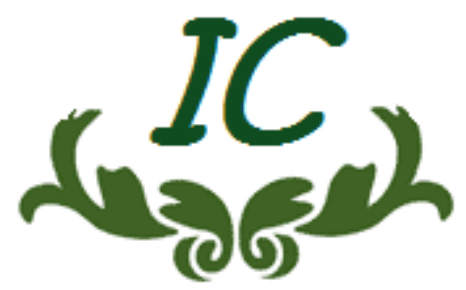

